\title{
Intracellular proteome expression during 4-n-nonylphenol biodegradation by the filamentous fungus Metarhizium robertsii
}

International Biodeterioration \& Biodegradation 93 (2014) 44-53

http://dx.doi.org/10.1016/j.ibiod.2014.04.026

Rafał Szewczyk ${ }^{\mathrm{a}}$, Adrian Sobońa ${ }^{\mathrm{a}}$, Różalska Sylwia ${ }^{\mathrm{a}}$, Katarzyna Dzitko $^{\mathrm{b}}$, Dietmar Waidelich $^{\mathrm{c}}$, Jerzy Długoński $^{\star}$

$\mathrm{a}^{*}$ Department of Industrial Microbiology and Biotechnology, Institute of Microbiology, Biotechnology and Immunology, Faculty of Biology and Environmental Protection, University of Łódź, Banacha 12/16, 90-237 Łódź, Poland, tel. 484263544 65, Fax. 484266558 18, jdlugo@biol.uni.lodz.pl

${ }^{\mathrm{b}}$ Department of Immunoparasitology, Institute of Microbiology, Biotechnology and Immunology, Faculty of Biology and Environmental Protection, University of Łódź, Banacha 12/16, 90-237 Łódź, Poland,

${ }^{\mathrm{c}} \mathrm{AB}$ SCIEX Germany GmbH, Landwehrstrasse 54, 64293 Darmstadt, Germany

\section{Abstract}

4-n-nonylphenol (4-n-NP) is an endocrine disrupting compound (EDC); pollutants that cause serious disturbances in the environment. This study shows the degradation pathway and initial proteome analysis in cultures of a fungus that actively degrades 4- $n$-NP, Metarhizium robertsii. The research revealed the presence of 14 4-n-NP metabolites formed as a result of the oxidation of the alkyl chain and benzene ring, which leads to the complete decomposition of the compound. Based on the trend and quantitative analysis of the formation of 4- $n$-NP derivatives, the best conditions for proteome analysis were established. The data collected allowed the formulation of an explanation of the microorganism's strategy towards the removal of $4-n-N P$. The main groups of proteins engaged in the removal of the xenobiotic are: oxidation-reduction systems related to nitroreductaselike proteins, ROS defense systems (peroxiredoxin and superoxide dismutase), the TCA cycle and energyrelated systems. Principal components analysis was applied to unidentified proteins, resulting in the formulation of three subgroups and initial classification of these proteins.

Keywords: Metarhizium robertsii, fungi, 4-nonylphenol, biodegradation, proteome, mass spectrometry.

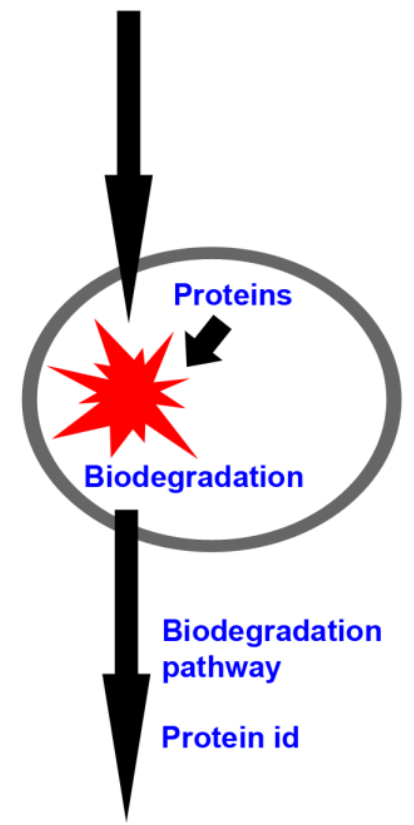

Xenobiotic removal

\section{Introduction}

Biodegradation of xenobiotics is a complex and multistage process involving different microorganism species and filamentous microscopic fungi play an important role in this process. There has been increasing interest in the capability of fungi to degrade organic pollutants, which has resulted the in characterization of strategies and biochemical pathways that lead to partial or complete removal of the toxic substances. Numerous substances enter the environment that can interfere with the endocrine system and damage ecosystems; among these are endocrine disruptor compounds (EDCs) such as 4-nonylphenol (4-NP) (Barlocher et al. 2011). 4-NP may cause growth disorders, decreased fertility and increased animal mortality. Humans also experience symptoms related to 4-NP exposure (Krupiński and Długoński 2011). The main source of 4-NP is microbial degradation of nonylphenol polyethoxylates (NPEOs), surfactants that are widely used in industrial and domestic products (Lintelmann et al. 2003; Vazquez-Duhalt et al. 2005; Corvini et al. 2006). 4-n-nonylphenol (4-n-NP) is a 4-NP isomer with a linear alkyl chain, used as an intermediate during the production of NPEOs and characterized by its toxicity and estrogenic activity in aquatic organisms (Lintelmann et al. 2003; Bonefeld-Jørgensen et al. 2007; Soares et al. 2008).

Better understanding of biodegradation mechanisms is essential to successful pollutant removal. To achieve this, metabolomic studies of biodegradation process, including proteome-based approaches, are required. Proteomic studies of filamentous fungi have only recently begun to appear in the literature, despite the prevalence of these organisms in the fields of biotechnology, industry and environmental protection and their importance as both human and plant pathogens (Kim et al. 2007; Doyle 2011; Bregar et al., 2012; Salvachúa et al. 2013; Kroll et al. 2014). Although the fungal biodegradation pathways of 4-NP have been proposed for several fungal organisms (Junghanns et al. 2005; Gabriel et al. 2008; Girlanda et al. 2009; Różalska et al. 2010; Krupiński et al. 2013), little is known about the proteomic background of these processes. In the current work, the 4- $n$-NP biodegradation pathway in the filamentous fungus, Metarhizium robertsii, which leads to the complete removal of the xenobiotic through consecutive oxidations of the alkyl chain followed by aromatic ring oxidation and the initial proteome background of 4-n-NP removal, was described. To our best knowledge, this is the first study of proteome expression in any microorganism in the presence of $4-n$-NP.

\section{Materials and methods}

\subsection{Strain and growth conditions}

Strain: The tested strain, Metarhizium robertsii IM 2358, was obtained from the fungal strain collection of the Department of Industrial Microbiology and Biotechnology, Institute of Microbiology, Biotechnology and Immunology, University of Łódź, Poland. The strain is capable of $4-n$-NP removal and phylogenetically belongs to the Metarhizium anisopliae complex (Różalska et al. 2013).

Growth conditions: Inoculum - spore solution obtained from 14-day old ZT slants (5 $\mathrm{ml}$ of Sabouraud medium (Difco, USA) per one slant) was transferred to an Erlenmeyer flask ( $\mathrm{V}=100 \mathrm{ml}$ ) containing $15 \mathrm{ml}$ of Sabouraud medium and incubated for $24 \mathrm{~h}$ at $28^{\circ} \mathrm{C}$ on a rotary shaker $(170 \mathrm{rpm})$. The $24 \mathrm{~h}$-old inoculum $(10 \%)$ was then transferred to Erlenmeyer flasks $(\mathrm{V}=100 \mathrm{ml})$ containing mineral medium X [15] with $50 \mathrm{mg} \mathrm{I}^{-1} 4-n$-NP (Sigma, Germany) addition (stock solution $20 \mathrm{mg} / \mathrm{ml}$ in ethanol). Cultures were then incubated on a rotary shaker $(140 \mathrm{rpm})$ at $28^{\circ} \mathrm{C}$. Samples for biodegradation studies and dry weight determination were collected every $24 \mathrm{~h}$ up to $120 \mathrm{~h}$ of culturing. Flasks containing cultures without 4-n-NP addition acted as biotic controls and inoculated flasks containing 4- $n$-NP acted as an abiotic control. A separate set of $24 \mathrm{~h}$ cultures with and without 4-n-NP addition was also used for proteomic studies. Every culture time point was prepared and analyzed in triplicate. All media ingredients were of high purity grade.

\subsection{Biodegradation studies}

Sample preparation, extraction, derivatization of 4-n-NP was performed as described previously (Różalska et al. 2010; Krupiński et al. 2013). Briefly, the samples were acidified

to $\mathrm{pH}=2$ with $1 \mathrm{M} \mathrm{HCl}$ and homogenized ultrasonically (MISONIX, England) with $20 \mathrm{ml}$ ethyl acetate (a first extraction step). Second step extraction was done with $20 \mathrm{ml}$ of methylene chloride. The mixed together extracts were dehydrated with anhydrous sodium sulfate and evaporated under reduced pressure at $40^{\circ} \mathrm{C}$. Dry extracts were dissolved in $1 \mathrm{ml}$ of ethyl acetate and $50 \mu \mathrm{l}$ of ethyl acetate solution was evaporated to dryness by a $\mathrm{N}_{2}$ gas stream and derivatized with the following procedure: $50 \mu \mathrm{l}$ of BSTFA (N,OBis(trimethylsilyl)trifluoroacetamide) (Sigma, Germany) was added and heated to $60^{\circ} \mathrm{C}$ for $1 \mathrm{~h}$. Afterwards, the samples were supplemented with $200 \mu \mathrm{l}$ ethyl acetate for qualitative GC-MS analysis.

GC-MS analysis: studies were performed using the workflow developed by our laboratory (Różalska et al. 2013) with minor 
modifications. The apparatus used was an Agilent 7890 gas chromatograph and Agilent 5975 Inert mass selective detector (Agilent, USA). Separations were performed on a HP-5MS capillary column with the dimensions - $30 \mathrm{~m} \times 0.25 \mathrm{~mm}$, film thickness 0.25 $\mu \mathrm{m}$ (Agilent, USA). Volumes of $2 \mu \mathrm{l}$ were injected in a split mode $\left(10: 1,300^{\circ} \mathrm{C}\right)$. Helium was used as a carrier gas with a flow rate 1.2 $\mathrm{ml} \mathrm{min}^{-1}$. The following gradient program was applied: the initial column temperature was set at $60^{\circ} \mathrm{C}$ for $3 \mathrm{~min}$, then increased at a rate $20^{\circ} \mathrm{C} \mathrm{min}{ }^{-1}$ to $290^{\circ} \mathrm{C}$ where it was maintained for $3 \mathrm{~min}$. Analysis was conducted in full-scan mode over a range of 44 to $500 \mathrm{~m} / \mathrm{z}$.

LC-MS/MS analysis: targeted quantitative analysis was performed on Agilent 1200 LC System (Agilent, USA) and AB Sciex QTRAP 3200 (AB Sciex, USA) mass detector. Samples obtained after extraction were dissolved in $2 \mathrm{ml}$ of acetonitrile (ACN) and diluted $(1: 10)$ with water prior to injection. Chromatography separation was conducted on an Agilent XDB-C18 $(2.1 \mathrm{~mm} \times 50 \mathrm{~mm} \times 1.8 \mu \mathrm{m})$ column: temperature $-40^{\circ} \mathrm{C}$, injection volume $-10 \mu \mathrm{l}$, injection wash $-3 \mathrm{~s}$ in flush port with ACN:propane-2-ol:water (1:1:1). The eluents were: water with $5 \mathrm{mM}$ of ammonium formate $(\mathrm{A})$ and ACN with 5 $\mathrm{mM}$ of ammonium formate. The gradient was a constant flow of 500 $\mu \mathrm{l} \mathrm{min}{ }^{-1}$. starting with: $90 \%$ of eluent $A$ and maintained for 2 min.; $10 \%$ of eluent $A$ in $10 \mathrm{~min}$.; $5 \%$ of eluent $A$ in 12 min. and maintained till $15 \mathrm{~min}$.; reversed to initial conditions for $3 \mathrm{~min}$. with $750 \mu \mathrm{l} \mathrm{min}{ }^{-1}$ flow for column stabilization. MS/MS detection and quantitation of 4n-NP (Sigma, Germany), 4-hydroxybenzoic acid (4-HBA) (Sigma, Germany), 4-hydroxyacetophenone (4-HAP) (Sigma, Germany) and 4-hydroxybenzaldehyde (4-HBAL) (Sigma, Germany) was made in negative ionization multiple reaction monitoring (MRM) mode. The optimized ESI ions source parameters were as follows: CUR: 25; IS: -4500 V; TEMP: $500^{\circ} \mathrm{C}$; GS1: 50; GS2:60 and ine:ON. Compounddependent MRM parameters are presented in the table S-1. Quantitation method curves fulfilled the criteria of limit of quantitation $(S / N \geq 10)$ and linearity $(r \geq 0,995)$ within the following working ranges: 4- $n$-NP - 1-10 $\mu \mathrm{g} \mathrm{ml}^{-1}, \mathrm{r}=0,9999 ; 4-\mathrm{HBA}-10 \mathrm{ng} \mathrm{ml}^{-1}-10 \mu \mathrm{g}$ $\mathrm{ml}^{-1}, \mathrm{r}=0,9975$; 4-HBAL - 10-1000 $\mathrm{ng} \mathrm{ml}^{-1}, \mathrm{r}=0$,9988; 4-HAP - 10$1000 \mathrm{ng} \mathrm{ml}^{-1}, \mathrm{r}=0,9983$. All ingredients used in LC-MS/MS analysis were of ultra-pure or LC-MS grade.

\subsection{Protein extraction}

After separation on Whatman 1 drains (Sigma, Germany), mycelium was washed with water and transferred to twisted Falcon vials $(\mathrm{V}=50$ $\mathrm{ml})$. Glass bed (1-mm diameter) and lytic buffer containing Tris- $\mathrm{HCl}$ (Sigma, Germany) ( $\mathrm{pH} 7.6)-20 \mathrm{mM}, \mathrm{NaCl}$ (Avantor, Poland) - 10 $\mathrm{mM}$, sodium deoxycholate (Serva, Germany) - $0.5 \mathrm{mM}$, EDTA (Sigma, Germany) - $1 \mathrm{mM}$ and PMSF (Sigma, Germany) $1 \mathrm{mM}$, was added to the sample in equal and doubled quantity in relation to the mycelium, respectively. Samples were homogenized on FastPrep24 (MP Biomedicals, USA) five times for $30 \mathrm{~s}$ with velocity of $4 \mathrm{~m} / \mathrm{s}$ and a 2 min. brake to brake for sample cooling while on ice. The homogenate obtained was then centrifuged for $20 \mathrm{~min}$. at $4^{\circ} \mathrm{C}$ at $40000 \mathrm{rpm}$. Supernatant was decanted to a new vial and was precipitated with 20\% TCA (Avantor, Poland) for $45 \mathrm{~min}$. on ice. Samples were then centrifuged for $10 \mathrm{~min} ., 4^{\circ} \mathrm{C}$ at $20000 \mathrm{~g}$. Protein precipitate was washed with cold acetone and centrifuged again as previously. Protein precipitate was then transferred to Eppendorf vials $(1,5 \mathrm{ml})$ and the remaining acetone was evaporated at $40^{\circ} \mathrm{C}$ for $2 \mathrm{~min}$. Protein residue was suspended in $100 \mu \mathrm{l}$ of $0.2 \mathrm{M} \mathrm{NaOH}$ (Avantor, Poland) for $2 \mathrm{~min}$. and SSSB buffer was added to obtain a final volume of $500 \mu \mathrm{l}$ (Nandakumar et al. 2003). Samples were stored at $-70^{\circ} \mathrm{C}$ for future use. All ingredients used in protein extraction were of high purity grade.

\subsection{1-D and 2-D electrophoresis}

Total protein content was measured using the Bradford method with BSA (Sigma, Germany) as the protein standard.

1-D electrophoresis: SDS-PAGE mini gels $(12.5 \%)$ were performed according to the procedure supplied with the electrophoresis set (Minipol 2, Kucharczyk Electrophoretic Techniques, Poland). Protein concentrations were normalized by dilution with SSSB buffer (Nandakumar et al. 2003). Next, samples were mixed with Laemmli Sample Buffer at a $1: 1(\mathrm{v} / \mathrm{v})$ ratio and incubated for $5 \mathrm{~min}$ at $99^{\circ} \mathrm{C}$ (without mass marker) in a thermoblock (Eppendorf, Germany). $20 \mu \mathrm{l}$ of each sample was added to the gel. Electrophoresis was conducted at $90 \mathrm{~V}$ for the stacking gel and $60 \mathrm{~V}$ for the running gel.
Gels were calibrated with a molecular mass marker 6500 - 200000 $\mathrm{Da}$ (Sigma, Germany) and stained with Coomassie blue.

2-D electrophoresis was done according to the procedure described by Długońska et al. (2001) with modifications. Total protein $(500 \mu \mathrm{g})$ was dissolved in $313 \mu \mathrm{l}$ of isoelectric focusing buffer (Rabilloud et al. 1997). Isoelectric focusing was performed on immobilized non-linear pH 3-11 gradient $13 \mathrm{~cm}$ IPG strips (GE-Healthcare, Germany) until reaching the value of $115114 \mathrm{VH}$. Second dimension SDS-PAGE was run on $12 \%$ running gel with a stacking gel on top. Electrophoresis was performed at $100 \mathrm{~V}$ for the stacking gel and at $220 \mathrm{~V}$ for the running gel (Hoefer, USA). Gels were calibrated with a molecular mass marker $6500-200000$ Da (Sigma, Germany) and stained with Coomassie blue. Analysis of the gels was performed using Image Master 2D Platinum 7 software (GE Healthcare, Germany).

\subsection{Protein digestion}

Protein digestion was done according to the Promega (http://pl.promega.com/resources/protocols/product-informationsheets/n/sequencing-grade-modified-trypsin-protocol, 2014) and UCSF (https://msf.ucsf.edu/ingel.html, 2014) procedure with minor modifications. Gel slices were diced into small pieces and placed into $1.5 \mathrm{ml}$ protein low-bind tubes (Eppendof). Gel pieces were washed with $100 \mu \mathrm{l}$ of $50 \mathrm{mM} \mathrm{NH} \mathrm{HCO}_{3}: A C N(50: 50 \mathrm{v} / \mathrm{v}$ ) and vortexed until completely decolorized and then dehydrated with 100 $\mu \mathrm{l}$ of ACN while being vortexed for $10 \mathrm{~min}$. The supernatant was discarded. Reduction and alkylation of band pieces was done by the addition of $50 \mu \mathrm{l} / \mathrm{b}$ and of $10 \mathrm{mM}$ DTT in $100 \mathrm{mM} \mathrm{NH} \mathrm{HCO}_{3}$ and incubated at $56^{\circ} \mathrm{C}$ for $30 \mathrm{~min}$. After discarding the supernatant, 50 $\mu \mathrm{l} /$ band of $50 \mathrm{mM}$ iodoacetamide in $100 \mathrm{mM} \mathrm{NH}_{4} \mathrm{HCO}_{3}$ was applied and incubated at room temperature for $30 \mathrm{~min}$. in the dark. The supernatant was discarded and the band pieces were washed two times with $100 \mu \mathrm{l}$ of $100 \mathrm{mM} \mathrm{NH}_{4} \mathrm{HCO}_{3}$ followed by $100 \mu \mathrm{l}$ of $\mathrm{ACN}$, both while being vortexed for $15 \mathrm{~min}$. After removal of the supernatant, band pieces were dried for $5-10 \mathrm{~min}$ at $37^{\circ} \mathrm{C}$. The gel pieces were covered in trypsin solution (Promega, USA) and incubated at $37^{\circ} \mathrm{C}$ overnight. The digest solution was then transferred into clean $1.5 \mathrm{ml}$ low-bind tubes. To the gel pieces, $30 \mu \mathrm{l}$ (or enough to cover) of $2 \% \mathrm{ACN}$ in $0.1 \%$ trifluoroacetic acid (TFA) was added and then the sample was vortexed for $20 \mathrm{~min}$. This step was repeated two times and the peptide containing supernatants were transferred into proper low-bind tubes. Prepared digests were stored at $4^{\circ} \mathrm{C}$ for future use.

\subsection{MALDI-TOF/TOF analysis}

The analysis was conducted on an AB Sciex 5800 TOF/TOF system (AB Sciex, USA). Samples were placed on the MALDI plate five times to cover the selection of the 50 strongest precursors for $\mathrm{MS} / \mathrm{MS}$ analysis. The TOF MS analysis was done in the mass range 700-4000 Da, $4000 \mathrm{~V} / 400 \mathrm{~Hz}$ laser relative energy with 2000 shots per sample. The precursor selection order in this mode was set from strongest to weakest. Instrument in TOF MS mode was first externally calibrated and then internally calibrated for every sample with $842.510 \mathrm{~m} / \mathrm{z}$ and $2211.106 \mathrm{~m} / \mathrm{z}$ (trypsin autolytic peptides). The TOF/TOF MS/MS analysis was conducted in the mass range 10$4000 \mathrm{Da}, 4550 \mathrm{~V} / 400 \mathrm{~Hz}$ laser relative power, CID gas (air) switched on at a pressure of ca $7 \times 10^{-7}$ and up to 4000 shots per precursor with dynamic exit. The precursor selection was set from weakest to strongest in this mode. The external calibration of MS/MS mode with the fragments of Glu-fibrinopeptide $(1570.677 \mathrm{~m} / \mathrm{z})$ was applied.

\subsection{Database searches}

AB Sciex Protein Pilot software v4.5 with Mascot search engine v2.4 (Perkins et al. 1999) applied was used for protein database searches. The data were searched against the NCBInr (version 12.2013) database with taxonomy filtering set to fungi (total number of sequences 34927437; total number of fungi sequences 3267418). MS/MS ion searches were performed with the following settings: trypsin was chosen as the protein digesting enzyme, up to two missed cleavages were tolerated, the following variable modifications were applied: Acetyl (N-term), Carbamidomethyl (C), Deamidated (NQ), Gln->pyro-Glu (N-term Q), Glu->pyro-Glu (N-term E), Oxidation (M), Phospho (ST) and Phospho (Y). Searches were done with a peptide mass tolerance of $50 \mathrm{ppm}$ and a fragment ion mass tolerance of $0.3 \mathrm{Da}$. Proteins unidentified by MASCOT 
searches were further processed using a BLAST (Altschul et al. 1990; http://blast.ncbi.nlm.nih.gov 2014) search against the nonredundant protein sequences database (34927437 sequences) with use of the BLASTP and DELTA-BLAST algorithms. The data for BLAST searches consisted of sets of single spot peptide sequences found with the use Data Explorer software (AB Sciex, USA).

\section{8. $P C A$ analysis}

Principle Components Analysis (PCA) (Ringnér 2008) using the MarkerView ${ }^{\mathrm{TM}}$ software (AB Sciex, USA) was performed on all fullscan single TOF MS data (peptide maps) after applying the master exclusion of common contaminants list (coming from MALDI matrix, trypsin peptides, keratin peptides and other present in all samples ions). After data set normalization against maximum and minimum values within the data set, the Pareto algorithm was applied for the PCA calculation. Discriminant Analysis (DA) was applied as a targeted PCA version where prior knowledge of sample groups (control sample and 4-n-NP sample in this case) is used to determine the variables that maximize the variation between groups and those which minimize the variation within a group.
HAP and 4-HBAL (fig. 2B, tab. S-2). The criteria for trend analysis was fulfilled by ion $179 \mathrm{~m} / \mathrm{z}$, which occurred in all byproducts of $4-n$ NP and its intensity was directly related to only one TMS group attached to hydroxyl substituent placed on $\mathrm{C}_{1}$ of the benzene ring. 4HBAL was chosen as a possible 4- $n$-NP biodegradation byproduct that occurs in many aerobic pathways for compounds containing a benzene ring with at least one aliphatic carbon substituent (Shaw and Harayama 1992; Spivack et al. 1994; Jorgensen et al. 1995). Both approaches aided in the formulation of the biodegradation pathway (fig. 3).

4- $n$-NP has a linear alkyl chain in its structure that undergoes a cascade of successive reactions which include; terminal hydroxylation of aliphatic carbon atoms, hydroxyl acid oxidation and removal of carbons in the $\beta$-oxidation pathway (Kim et al. 2007; Girlanda et al. 2009; Barlocher et al. 2011; Doyle 2011). Analysis of the compound removal by the tested strain shows that the decomposition of the xenobiotic undergoes consecutive oxidation of the alkyl chain and results in the formation of carboxylic acids, aldehydes or dihydroxylated carboxylic acids, leading to the final formation 4-hydroxybenzoic acid and 3,4-hydroxybenzoic acid (fig. 3). Biodegradation of $4-n-N P$ by the tested strain is similar to the

Table 1. GC-MS results of qualitative analysis of 4-nonylphenol biodegradation.

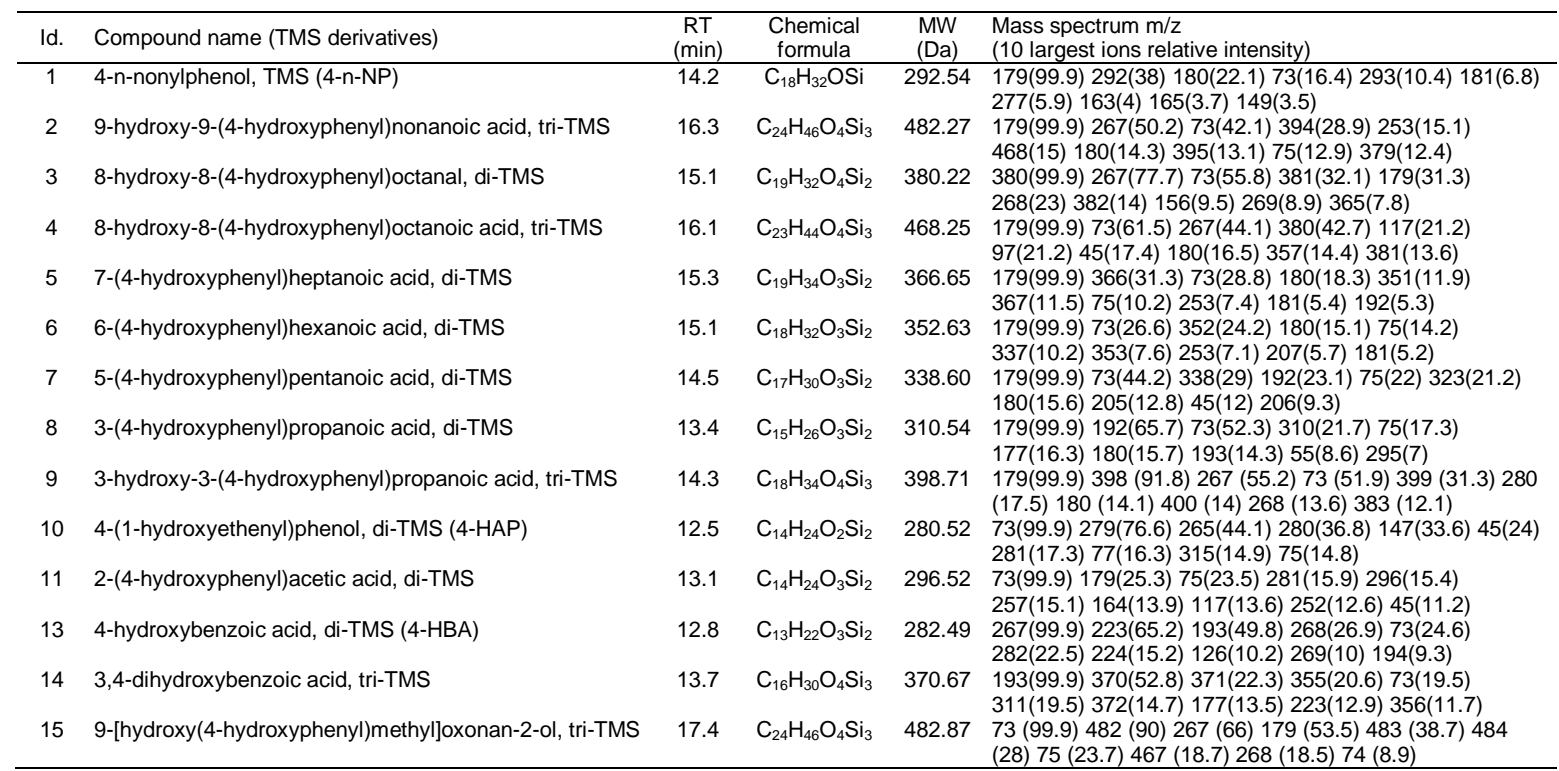

\section{Results and discussion}

\subsection{4-n-NP biodegradation}

GC-MS analysis was performed according to the previously developed method (Różalska et al. 2010). Identified metabolites of 4-n-NP presented typical fragmentation pattern: long chain derivatives - molecular ion (M) followed by loss of $15 \mathrm{~m} / \mathrm{z}(\mathrm{CH} 3)$, $179 \mathrm{~m} / \mathrm{z}$ - base peak (CH2-Ar(aromatic ring)-O-TMS), $73 \mathrm{~m} / \mathrm{z}$ (TMS), $91 \mathrm{~m} / \mathrm{z}(\mathrm{Ar}), 105 \mathrm{~m} / \mathrm{z}(\mathrm{Ar}-\mathrm{OH})$ and $45 \mathrm{~m} / \mathrm{z}(\mathrm{COO})$; short chain compounds - molecular ion (M) followed by loss of $15 \mathrm{~m} / \mathrm{z}(\mathrm{CH} 3)$, strong $193 \mathrm{~m} / \mathrm{z}$ coming from Ar-COO-TMS (as a result of detachment of O-TMS from the aromatic ring), $73 \mathrm{~m} / \mathrm{z}$ from TMS, 91 $\mathrm{m} / \mathrm{z}(\mathrm{Ar}), 105 \mathrm{~m} / \mathrm{z}(\mathrm{Ar}-\mathrm{OH})$ and $45(\mathrm{COO})$. The presence of the majority of compounds was confirmed using NIST12 Mass Spectra Database searches with probability ranging from $90 \%$ to $99 \%$. Mass spectra of identified metabolites are shown in table 1 . The proposed structure of 9-[hydroxy(4-hydroxyphenyl)methyl)oxonan-2-ol (fig. 1) is based on a lack of abundant fragmentation ions between ion 482 $\mathrm{m} / \mathrm{z}$ (molecular ion) and ion $267 \mathrm{~m} / \mathrm{z}$ which we assumed was a result of molecule stabilization by the formation of a cyclic aliphatic substructure within a nonyl moiety. Presence of this compound is in agreement with the rapid formation (24 h) of 4-hydroxybenzoic acid and explains the mechanism of this reaction.

Further analysis of $4-n$-NP biodegradation was conducted as a qualitative trend analysis of the remaining compounds by comparing the extracted ion peak area (fig. 2A) with the targeted LC-MS/MS quantitative analysis of selected compounds - 4-n-NP, 4-HBA, 4-

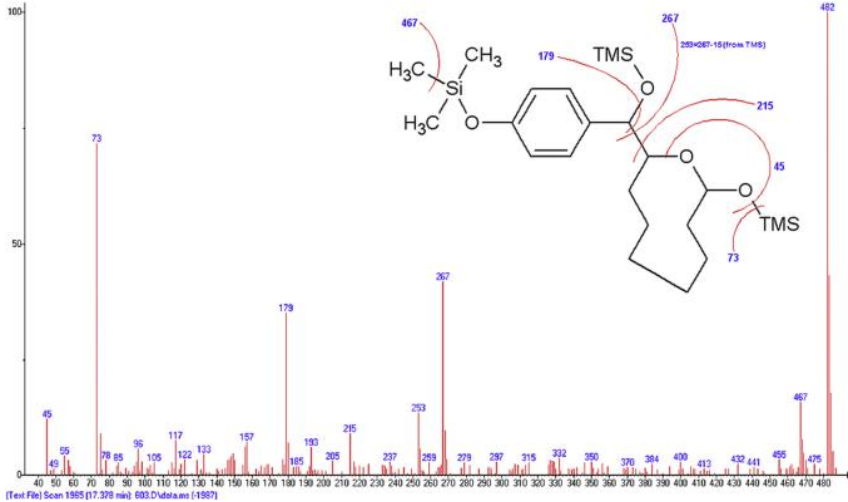

Fig. 1. Interpretation and mass spectra of 9-[hydroxy(4hydroxyphenyl)methyl)oxonan-2-ol.

A. versicolor (Krupiński et al. 2013) and G. simplex (Różalska et al. 2010) pathways, except for the presence of the following metabolites which appear to be unique for the $M$. robertsii strain: 9-[hydroxy(4hydroxyphenyl)methyl]oxonan-2-ol, hydroxyphenyl)propanoic acid and 4-HBAL. 3-hydroxy-3-(4- 


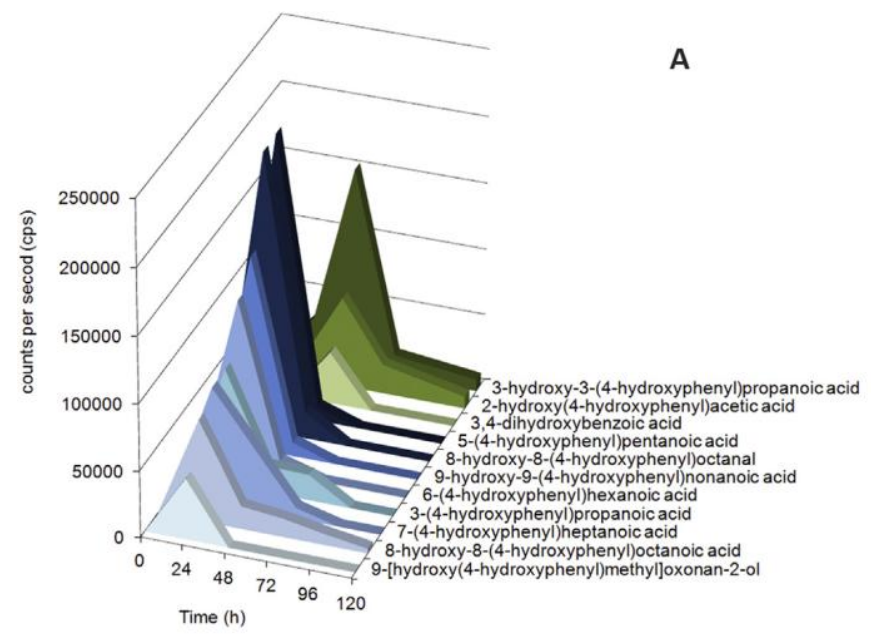

Fig. 2. A - trend analysis of 4-n-NP biodegradation products based on GCeMS data on ion $179 \mathrm{~m} / \mathrm{z}$ area and B - LC-MS/MS targeted quantitative analysis of 4-n-NP and selected metabolites, during the culture of $M$. robertsii on mineral medium $\mathrm{X}$.

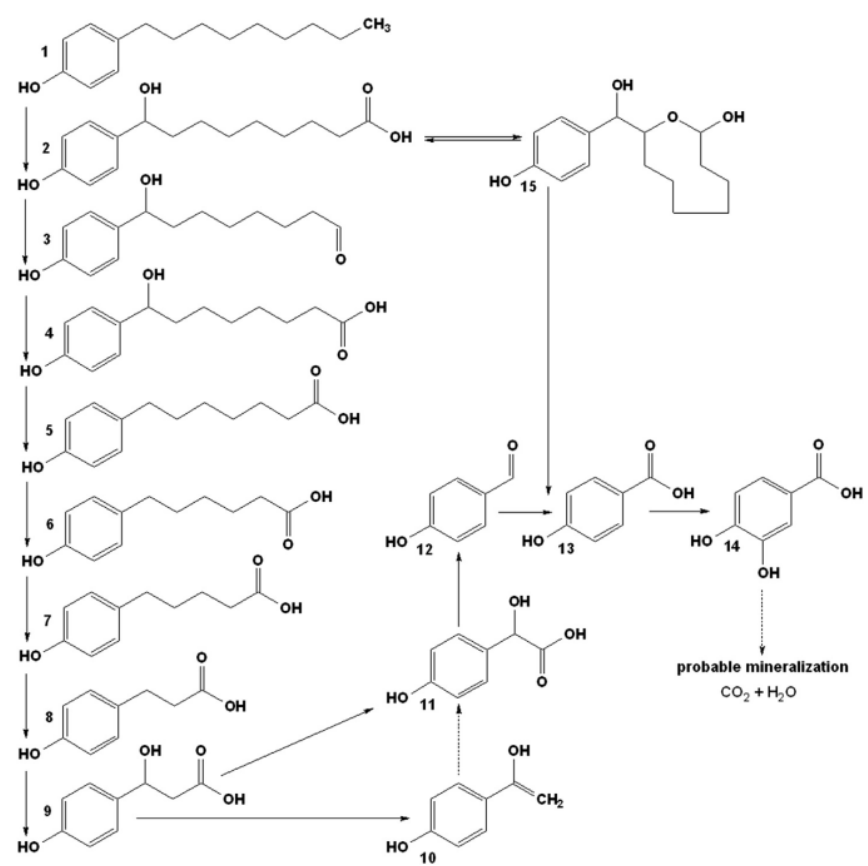

Fig. 3. The 4-n-NP biodegradation pathway conducted by $M$. robertsii.

\subsection{Proteomic background of 4-n-NP biodegradation}

The dry weight curves (fig. S-1) show that control and 4-n-NP containing cultures are in the logarithmic phase of growth until $48 \mathrm{~h}$ of culturing, reaching $4.987 \mathrm{~g} \mathrm{I}^{-1}$ and $4.762 \mathrm{~g} \mathrm{I}^{-1}$, respectively. However, biodegradation trend analysis (fig. $2 \mathrm{~A}$ ) and quantitative analysis (fig. 2B) revealed that after $24 \mathrm{~h}$ of incubation more than $60 \%$ of $4-n$-NP was removed and the majority of its derivatives reached the concentration apex at this point of culturing. Five compounds - 3,4-dihydroxybenzoic acid, 2-(4-hydroxyphenyl) acetic acid, 3-hydroxy-3(4-hydroxyphenyl)propanoic acid, 4-HAP and 4HBAL reached their maximum within $48 \mathrm{~h}$ of the experiment, but they were also detected after $24 \mathrm{~h}$ of culture. According to the data obtained after separate homogenized mycelium and culture medium extractions, removal of the xenobiotic takes place inside the cells of tested strain. Therefore, mycelium samples collected after $24 \mathrm{~h}$ of culturing were determined as the best suited for intracellular proteome expression studies.

Proper protein extraction is essential for fungal cell proteome research (Shimidzu and Wariishi 2005; Kim et al. 2007; Bhadauria et al.

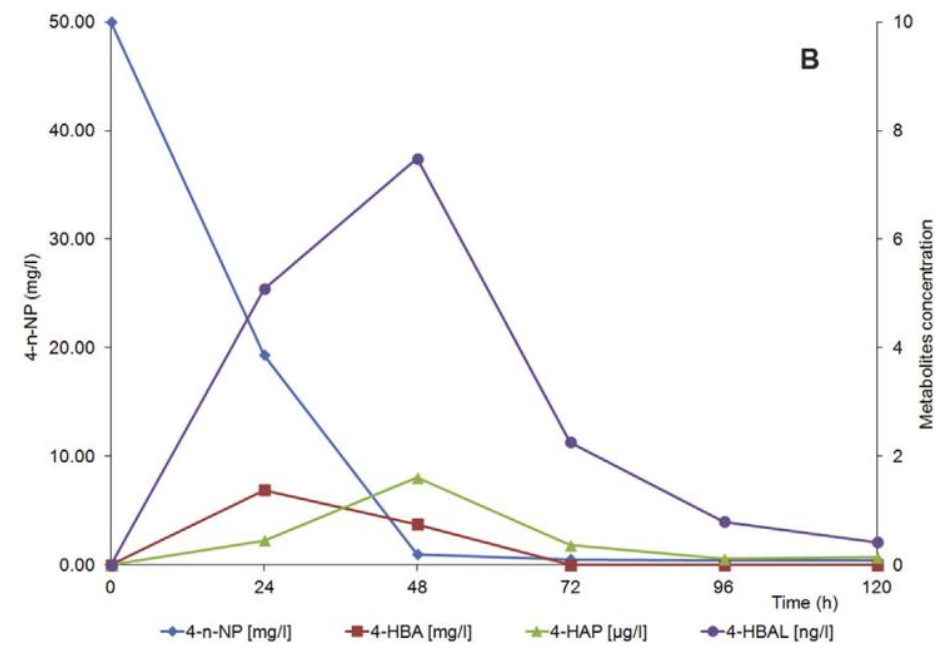

2007); as this group of microorganisms secrete proteases, display polarized growth supported by microtubules that increase the clustering of different organelles and may possess thick, compact cell walls (Ferreira de Oliveira and de Graaff 2011). In this study the method of mechanical disintegration of the cells by using glass matrix spheres (Taubert et al. 2000) followed by TCA precipitation of proteins, was optimized (Bhadauria et al. 2007; Isola et al. 2011).

\subsubsection{1-D and 2-D electrophoresis}

Proteins obtained from test and control samples after $0 \mathrm{~h}, 24 \mathrm{~h}, 48 \mathrm{~h}$ and $72 \mathrm{~h}$ of culturing were initially analyzed on 1-DE gels (fig. 4). The 1-DE SDS-PAGE after $24 \mathrm{~h}$ of culturing showed the greatest number (8) of differentially expressed proteins. Proteins that were over expressed after $24 \mathrm{~h}$ of culturing had bands at the following relative molecular masses: $88.7 \mathrm{kDa}, 52.8 \mathrm{kDa}, 40.2 \mathrm{kDa}, 34.2 \mathrm{kDa}$, $31.7 \mathrm{kDa}, 22.9 \mathrm{kDa}, 20 \mathrm{kDa}$ and $16 \mathrm{kDa}$. The protein band at 31.7 $\mathrm{kDa}$ was the only protein overexpressed in the control sample, the remaining proteins had a higher intensity in the test sample. After 48 $\mathrm{h}$ of culturing, 5 differences were observed in the expression of proteins at the following relative molecular mass: $88.7 \mathrm{kDa}, 52.8$ $\mathrm{kDa}, 40.2 \mathrm{kDa}, 34.2 \mathrm{kDa}, 22.9 \mathrm{kDa}$. These proteins were only over expressed in the test sample.

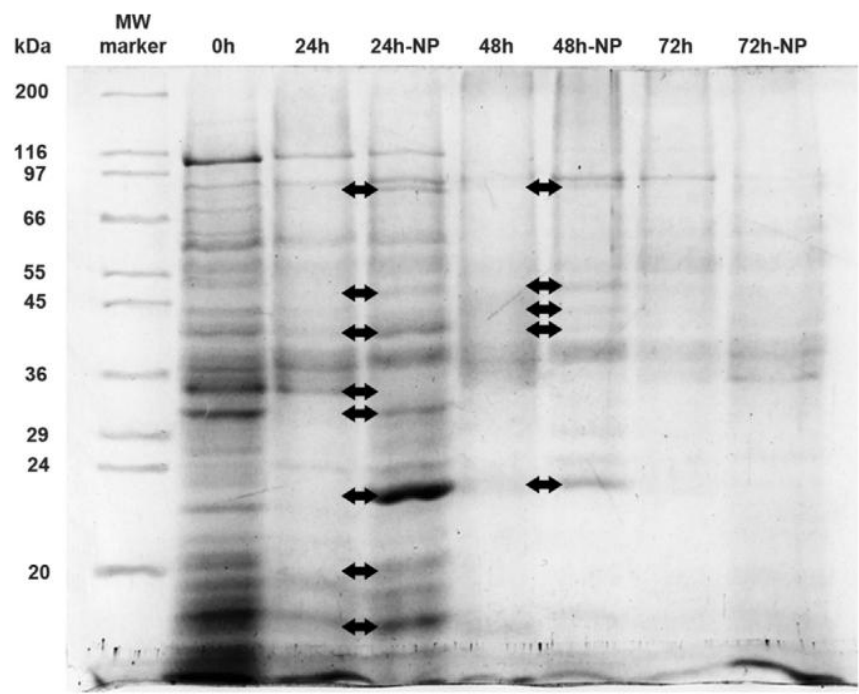

Fig. 4. 1-D SDS-PAGE electrophoresis analysis of the M. robertsil proteome in the absence or presence (NP) of 4-n-NP

2-DE analysis revealed the expression of 205 spots in the control culture and 208 spots in cultures with $4-n$-NP addition. 88 spots were matched in both gels. When the test culture was compared with the sample with 4- $n$-NP addition, 47 proteins decreased and 41 proteins increased their relative intensity, however, the differences between matched spots were not significant (below 1-fold). The most significant differences (large spots) between the samples included: 

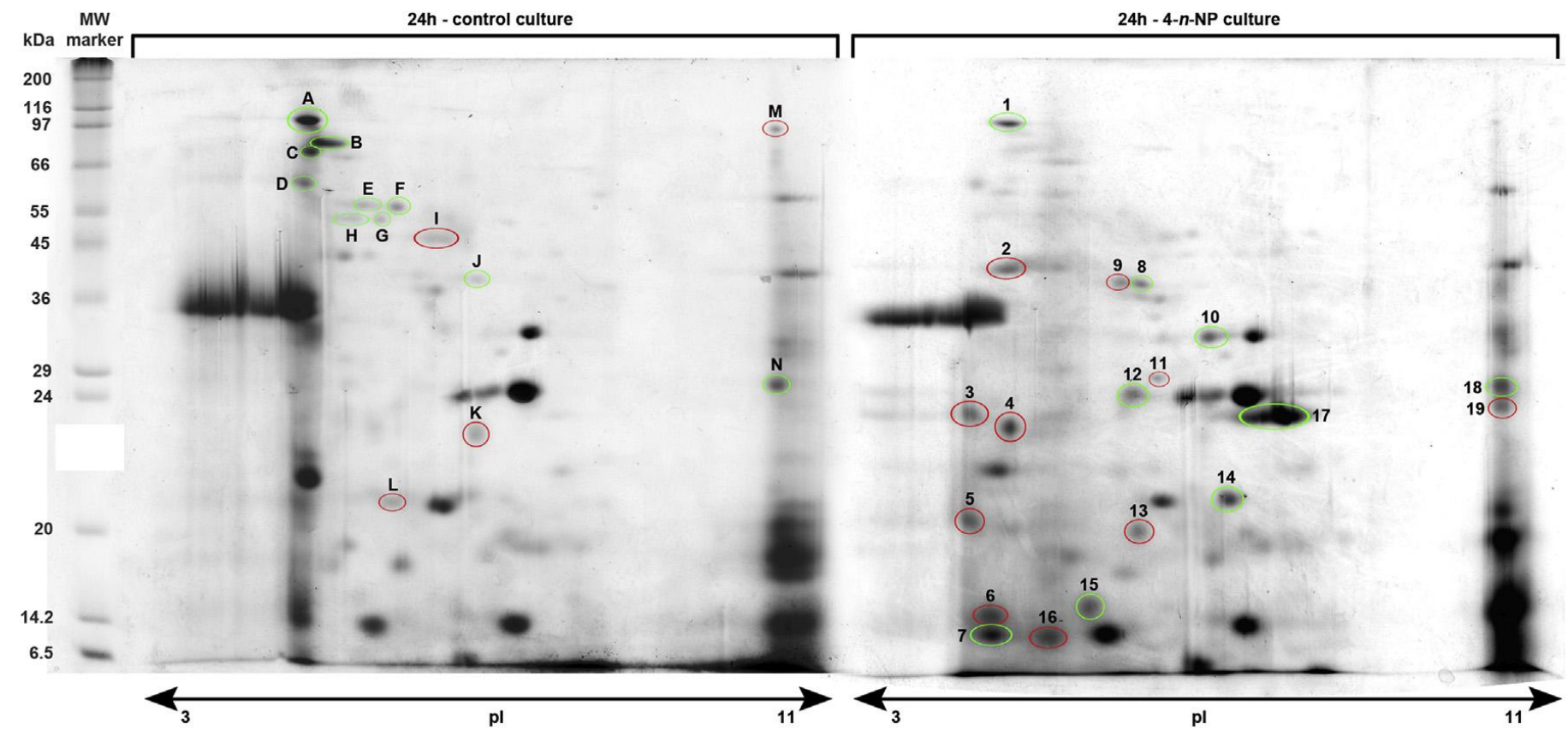

Fig. 5. 2-D electrophoresis gels after $24 \mathrm{~h}$ of culturing. Marked spots were analyzed by MALDI-TOF/TOF: red circles - unidentified proteins, green circles - identified proteins.

14 protein spots present only in control samples and 19 protein spots present only in xenobiotic containing cultures (fig. 5). To the best of our knowledge, this is the first report detailing proteome expression in any microorganism in the presence of 4-n-NP.

One study on the $M$. anisopliae proteome referred to its bioinsecticide activity against Callosobruchus maculates (Murad et al. 2006), yet, the authors focused on extracellular proteins and found proteases, reductases and acetyltransferase enzymes that may be involved in degradation and nutrient uptake from dehydrated C. maculatus. In an additional study, whole fungal cell analysis was

performed to study proteome involvement in benzoic acid biodegradation by the white-rot fungus, Phanerochaete chrysosporium (Matsuzaki et al. 2008). In this study, over 600 protein spots were observed in 2-DE gels. In samples containing benzoic acid, two-fold higher expression (or absence in control sample) for 50 proteins and decreased expression for 80 proteins were observed. After MS/MS analysis was used for identification, proteins were grouped into seven classes including: heat shock proteins, enzymes involved in biodegradation or glycolysis enzymes. Whole proteome analysis was also presented by Carvalho at al. (2013) for pentachlorophenol (PCP) biodegradation by Mucor plumbeus. 2-D gel analysis revealed presence of over 700 protein spots in control and PCP-treated cultures. On the basis of identified proteins, it was shown that upon exposure to the toxicant, over-

Table 2. Summary of Mascot search results. Green - identified (high score and/or high sequence coverage), red - unidentified (low score). Mascot algorithm matching - protein scores greater than 73 are significant $(p<0.05)$.

\begin{tabular}{|c|c|c|c|c|c|c|}
\hline ID & Protein Accession & MW (Da) & $\mathrm{pl}$ & Seq. Cov. (\%) & $\begin{array}{l}\text { Mascot } \\
\text { Score }\end{array}$ & Protein Description \\
\hline a & gi|322712074 & 53925 & 5.14 & 47 & 347 & immunogenic protein [Metarhizium anisopliae ARSEF 23] \\
\hline b & gi|322712074 & 53925 & 5.14 & 56 & 672 & immunogenic protein [Metarhizium anisopliae ARSEF 23] \\
\hline c & gi|322712074 & 53925 & 5.14 & 24 & 74 & immunogenic protein [Metarhizium anisopliae ARSEF 23] \\
\hline d & gi|322708836 & 25878 & 5.88 & 39 & 161 & extracellular matrix protein precursor [Metarhizium anisopliae ARSEF 23] \\
\hline e & gi|322712590 & 36538 & 5.80 & 31 & 93 & RNP domain protein [Metarhizium acridum CQMa 102] \\
\hline$f$ & gi|322694217 & 38824 & 5.80 & 55 & 138 & glycine-rich protein [Metarhizium anisopliae ARSEF 23] \\
\hline g & gi|322712591 & 36539 & 5.80 & 68 & 76 & glycine-rich protein [Metarhizium anisopliae ARSEF 23] \\
\hline $\mathrm{h}$ & gi|322712591 & 36539 & 5.69 & 37 & 88 & glycine-rich protein [Metarhizium anisopliae ARSEF 23] \\
\hline $\mathrm{i}$ & - & - & - & - & - & no match \\
\hline $\mathrm{j}$ & gi|322711158 & 30416 & 6.0 & 52 & 267 & vip1 [Metarhizium anisopliae ARSEF 23] \\
\hline $\mathrm{k}$ & gi|170106511 & 73245 & 8.9 & 11 & 44 & predicted protein [Laccaria bicolor S238N-H82] \\
\hline 1 & gi|358060715 & 113470 & 8.4 & 16 & 48 & hypothetical protein E5Q_00127 [Mixia osmundae IAM 14324] \\
\hline $\mathrm{m}$ & gi|302666331 & 79138 & 9.6 & 8 & 37 & hypothetical protein TRV_01048 [Trichophyton verrucosum HKI 0517] \\
\hline $\mathrm{n}$ & gi|322711195 & 23843 & 11.1 & 46 & 80 & 60S ribosomal protein L13 [Metarhizium anisopliae ARSEF 23] \\
\hline 1 & gi|322712074 & 53925 & 5.1 & 49 & 232 & immunogenic protein [Metarhizium anisopliae ARSEF 23] \\
\hline 2 & gi|342882959 & 18677 & 9.1 & 22 & 46 & hypothetical protein FOXB_05933 [Fusarium oxysporum Fo5176] \\
\hline 3 & gi|322710763 & 228390 & 5.3 & 43 & 75 & filament-forming protein [Metarhizium anisopliae ARSEF 23] \\
\hline 4 & gi|342882959 & 18677 & 9.1 & 18 & 56 & hypothetical protein FOXB_05933 [Fusarium oxysporum Fo5176] \\
\hline 5 & gi|328851184 & 25457 & 6.3 & 11 & 37 & hypothetical protein MELLADRAFT_67879 [Melampsora larici-populina 98AG31] \\
\hline 6 & gi|358060715 & 113470 & 8.3 & 9 & 42 & hypothetical protein E5Q_00127 [Mixia osmundae IAM 14324] \\
\hline 7 & gi|322712463 & 63038 & 6.7 & 39 & 78 & pyruvate dehydrogenase kinase [Metarhizium anisopliae ARSEF 23] \\
\hline 8 & gi|322708858 & 39150 & 5.98 & 63 & 84 & inorganic pyrophosphatase [Metarhizium anisopliae ARSEF 23] \\
\hline 9 & gi|342882959 & 18677 & 9.1 & 20 & 47 & hypothetical protein FOXB_05933 [Fusarium oxysporum Fo5176] \\
\hline 10 & gi|322707901 & 34979 & 8.62 & 74 & 322 & malate dehydrogenase [Metarhizium anisopliae ARSEF 23] \\
\hline 11 & gi|342882959 & 18677 & 9.1 & 18 & 46 & hypothetical protein FOXB_05933 [Fusarium oxysporum Fo5176] \\
\hline 12 & gi|322706086 & 24558 & 6.43 & 48 & 141 & mitochondrial peroxiredoxin PRX1 [Metarhizium anisopliae ARSEF 23] \\
\hline
\end{tabular}




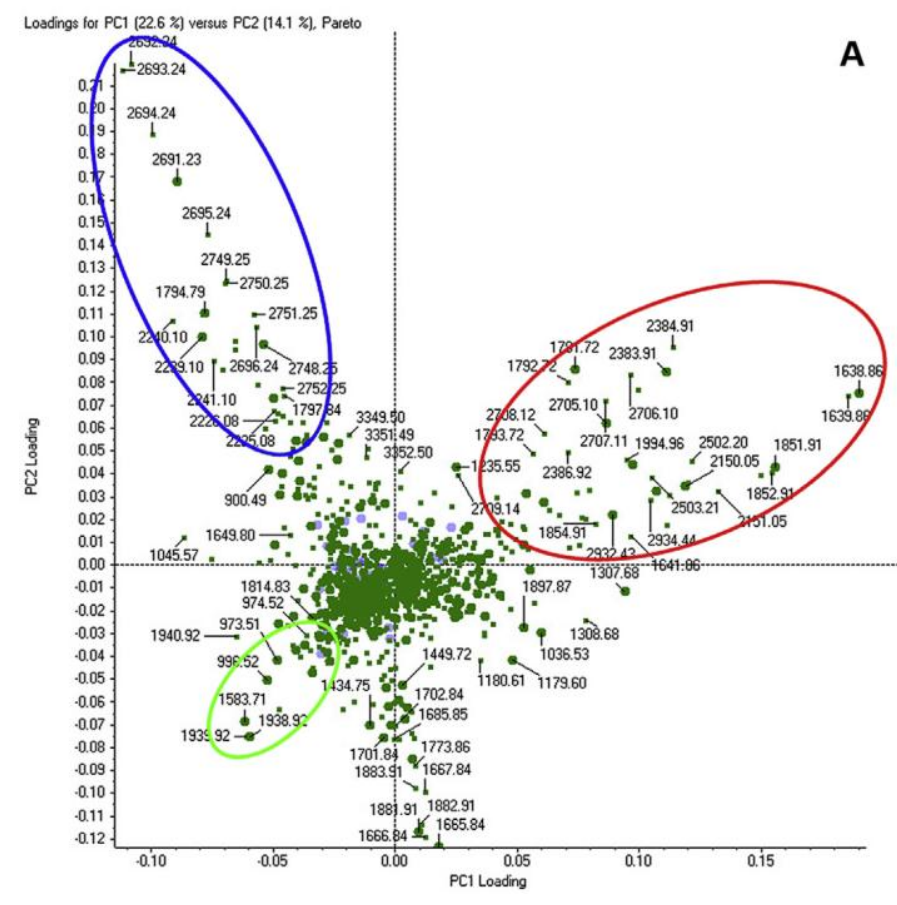

Fig. 6. PCA analysis of the peptide maps (TOF MS data) e A e PC1 against PC2 loadings chart, B - PC1 against PC2 scores chart. Group 1 - green circle (extracellular cell-wall proteins), group 2 - blue circle (structural and nucleotide binding proteins), group 3 - red circle (enzymes).

accumulation of several protein spots were observed that correspond to proteins involved in defense mechanisms against stress (e.g., HSP70, cytochrome c peroxidase and thiamine biosynthetic enzymes). However, the revealed PCP pathway does not involve any of the mycelial or extracellular proteins, with the exception of the ADH mycelial protein; which seems to be involved in the last steps of PCP degradation.

\subsubsection{MALDI-TOF/TOF protein identification}

In the current work, overexpressed proteins from both tested systems were examined. Following tryptic digestion, peptide maps and peptide sequences were analyzed on a MALDI-TOF/TOF instrument. To identify the tested proteins, database searches with Mascot Search Engine and BLAST searches were performed. The database search results are presented in table 2. As it is shown in table 2 , out of the 14 upregulated proteins in the control samples, we identified 10 proteins: immunogenic protein (three isoforms), extracellular matrix protein precursor, glycine-rich protein (three isoforms), vip1, 60S ribosomal protein L13 from M. anisopliae and RNP domain protein from Metarhizium acridum. Although RNP domain protein was identified as coming from the Metarhizium genus, it had a good score and sequence coverage, reflecting high homology to the database sequence. In case of upregulated proteins coming from the culture with 4- $n$-NP addition, 10 out of 17 proteins were identified: immunogenic protein, filament-forming protein (2 isoforms), pyruvate dehydrogenase kinase, inorganic pyrophosphatase, malate dehydrogenase, mitochondrial peroxiredoxin PRX1 (2 isoforms), superoxide dismutase and nitroreductase family protein. The main mechanism of the 4- $n$-NP biodegradation is consecutive oxidation of $\mathrm{C}-\mathrm{C}_{\text {terminal }}$ atoms of the aliphatic chain leading to formation of carboxylic acids coupled with $\mathrm{C}_{\text {terminal }}$ carbon removal. The proteomic data obtained in this study cannot clearly explain the mechanism of the 4-n-NP biodegradation in the tested fungal strain, but allow the formulation of hypotheses that the overexpressed enzymes in the cultures with 4- $n$-NP addition could play a role in xenobiotic removal, toxicity defense mechanisms or other mechanisms involved in the biodegradation process. The first main difference between the two sample sets is that within examined proteins in the control sample, cell-wall structural proteins and nucleotide binding proteins are dominant; while in the sample with 4- $n$-NP addition, the majority of identified proteins are dominated by oxygenation - reduction enzymes. The largest tested

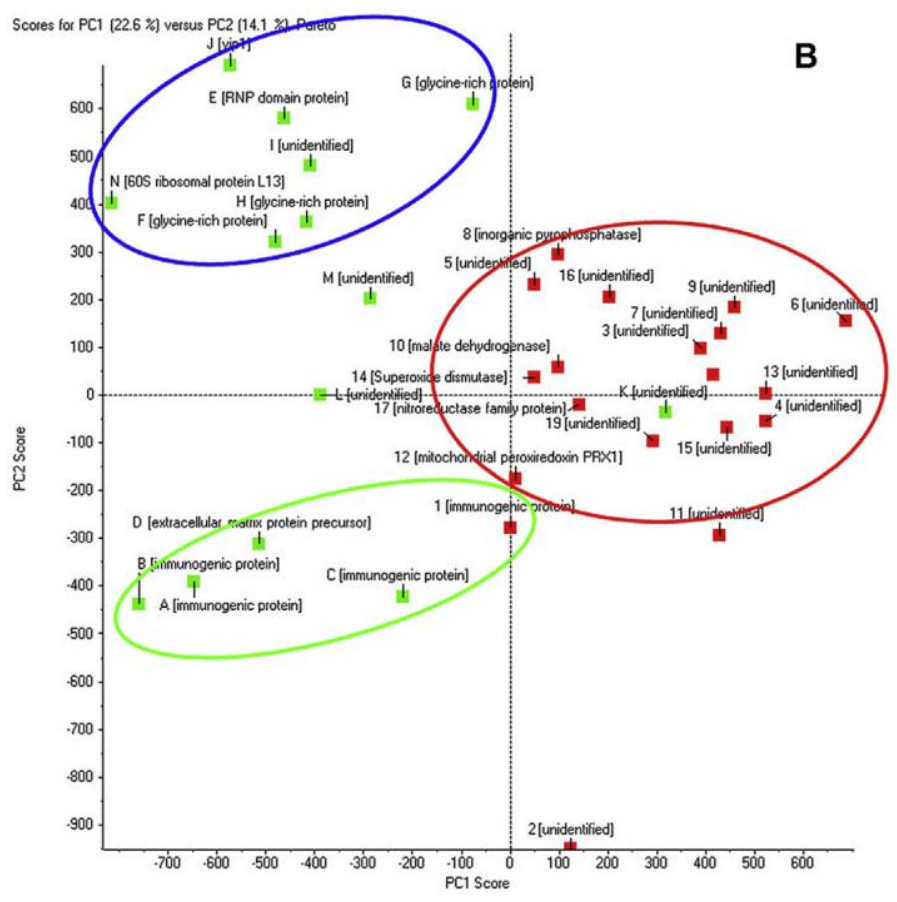

2-DE spot in the samples from 4-n-NP containing cultures was identified as nitroreductase family protein, which may act as a nitroreductase-like protein; a protein which belongs to an uncharacterized protein family that is functionally related to type II nitroreductase enzymes (oxygen-sensitive) that are found in various organisms, especially eukaryotes. These include aldehyde oxidase, cytochrome c oxidase, NADPH, cytochrome P-450 reductase and others (Oliveira et al. 2005). The overexpression of mitochondrial peroxiredoxin PRX1 and superoxide dismutase in the cultures with 4- $n$-NP may suggest that reactive oxygen species (ROS) are generated (Gertz et al. 2009). ROS are very reactive and toxic to cell homeostasis and if they are generated during the biodegradation process, both enzymes may possibly act as a part of antioxidant defense system. However, the oxidoreductase activity of PRX1 cannot be excluded because expression of this enzyme takes place under other physiological and non-physiological conditions (Fujii and Ikeda 2002). In the cultures containing 4- $n$-NP were also identified two energy-related enzymes: inorganic pyrophosphatase and pyruvate dehydrogenase kinase. The first enzyme delivers phosphate from inorganic compounds, while the second enzyme transfers one or more phosphate groups to a substrate; for example, by interacting with ATP. The high intensity of malate dehydrogenase - an enzyme that reversibly catalyzes the oxidation of malate to oxaloacetate using the reduction of $\mathrm{NAD}^{+}$to $\mathrm{NADH}$ was also observed in the xenobiotic containing cultures. Oxidation of the benzene ring to a catechol derivative at the end of the observed pathway (fig. 3) results in formation of 3,4-dihydroxybenzoic acid and is usually catalyzed by cytochrome P-450 oxidoreductases (Dehal and Kupfer 1999; Bamforth and Singleton 2005; Zhang et al. 2007), but none of cytochrome P-450 oxidoreductases was identified in the current research.

\subsubsection{PCA analysis of peptide maps}

There are increasing number of publications that use PCA for complex proteome analyses in different species and different data types using PC loadings (Verhoeckx et al. 2004; Rao and Li 2009; Shao et al. 2012). BLAST searches did not result in any reasonable results for the unidentified proteins; therefore, a principal components analysis (PCA) was employed to propose a role for the unknown proteins (fig. 6). The analysis was performed with the use of MarkerView ${ }^{\mathrm{TM}}$ software on all full-scan single TOF MS data, which are peptide maps for the selected samples. PCA scores of similar samples tend to form clusters, while different samples are found at greater mutual distances as presented in fig. 3A and 3B. The PCA of TOF MS data forms three main groups denoted as: extracellular cellwall proteins (1), structural and nucleotide binding proteins (2) and enzymes (3). Although these data did not aid in the identification of unknown proteins, the results allowed to speculate that most of the 
unidentified proteins within group 3 are enzymes directly or partially involved in the 4- $n$-NP biodegradation by $M$. robertsii.

\section{Conclusion}

Deeper insight into the process of $4-n$-NP biodegradation by $M$. robertsii was achieved by the formulation of the biodegradation pathway and proteome expression analysis. Research on the degradation pathway revealed the presence of 14 4-n-NP metabolites formed as a result of the oxidation of the alkyl chain and benzene ring, leading to complete decomposition of the compound. Among the tested proteins, over $60 \%$ were identified. PCA divided the data into three subgroups that allowed the initial classification of unidentified proteins. The data collected let to formulate an explanation of the microorganism's strategy towards 4- $n$-NP and explained the basics of the proteomic background involved in oxidation-reduction systems, ROS defense systems, the TCA cycle and energy-related systems in the EDCs xenobiotic removal.

\section{Acknowledgments}

This study was supported by the grant of the National Science Centre, Poland (Project No. UMO-2011/01/B/NZ9/02898). We thank Baljit Ubhi from AB Sciex Germany for the fruitful discussion on PCA.

\section{References}

Altschul, S.F., Gish, W., Miller, W., Myers, E.W., Lipman, D.J. 1990. Basic local alignment search tool. Journal of Molecular Biology 215, 403-410.

Bamforth, S.M., Singleton, I., 2005. Bioremediation of polycyclic aromatic hydrocarbons: current knowledge and future directions. Journal of Chemical Technology and Biotechnology 80, 723-736.

Barlocher, F., Guenzel, K., Sridhar, K.R., Duffy, S.J., 2011. Effects of 4-n-nonylphenol on aquatic hyphomycetes. Science of Total

Environment 409, 1651-1657.

Basic Local Alignment Search Tool 2014. Online at: http://blast.ncbi.nlm.nih.gov/

Bhadauria, V., Sheng, Z.W., Wang, L., Zhang, Y., Liu, Y., Yang, J., Kong, L., Peng, Y., 2007. Advances in fungal proteomics. Microbiology Research 162, 193-200.

Bonefeld-Jørgensen, E.C., Long, M., Hofmeister, M.V., Vinggaard, A.M., 2007. Endocrine-disrupting potential of bisphenol A, bisphenol A dimethacrylate, 4-n-nonylophenol, and 4- $n$-octylphenol in vitro: new data and a brief review. Environmental Health Perspectives 115, 69-76.

Bregar, O., Mandelc, S., Celar, F., Javornik, B., 2012. Proteome Analysis of the Plant Pathogenic Fungus Monilinia laxa Showing Host Specificity. Food Technology and Biotechnology 50(3), 326333.

Carvalho, M.B., Martins, I., Medeiros, J., Tavares, S., Planchon, S., Renaut, J., Núñez, O., Gallart-Ayala, H., Galceran, M.T., Hursthouse, A., Silva Pereira, C., 2013. The response of Mucor plumbeus to pentachlorophenol: A toxicoproteomics study. Journal of Proteomics 78, 159-171.

Corvini, P.F.X., Schäffer, A., Schlosser, D., 2006. Microbial degradation of nonylphenol and other alkylphenols - our evolving view. Applied Microbiology and Biotechnology 72, 223-243.

Dehal, S.S., Kupfer, D., 1999. Cytochrome P-450 3A and 2D6 catalyze ortho hydroxylation of 4-hydroxytamoxifen and 3hydroxytamoxifen (droloxifene) yielding tamoxifen catechol: involvement of catechols in covalent binding to hepatic proteins. Drug Metabolism and Disposition 27(6), 681-688.

Długońska, H., Dytnerska, K., Reichmann, G., Stachelhaus, S., Fischer, H.G., 2001. Towards the Toxoplasma gondii proteome: position of 13 parasite excretory antigens on a standardized map of two-dimensionally separated tachyzoite proteins. Parasitology Research 87(8), 634-637.

Doyle, S.S., 2011. Fungal proteomics: from identification to function. FEMS Microbiology Letters 321, 1-9.

Ferreira de Oliveira, J.M.P.F., de Graaff L.H., 2011. Proteomics of industrial fungi: trends and insights for biotechnology. Applied Microbiology and Biotechnology 89, 225-237.

Fujii, J., Ikeda, Y., 2002. Advances in our understanding of peroxiredoxin, a multifunctional, mammalian redox protein. Redox Report 7(3), 123-30.
Gabriel, F.L., Routledge, E.J., Heidlberger, A., Rentsch, D., Guenther, K., Giger, W., Sumpter, J.P., Kohler, H.P., 2008. Isomerspecific degradation and endocrine disrupting activity of nonylphenols. Environmental Science and Technology 42, 63996408.

Gertz, M., Fischer, F., Leipelt, M., Wolters, D., Steegborn, C., 2009. Identification of Peroxiredoxin 1 as a novel interaction partner for the lifespan regulator protein p66Shc. Aging 30(2), 254-65.

Girlanda, M., Favero-Longo, S.E., Lazzari, A., Segreto, R., Perotto, S., Siniscalco, C., 2009. Indigenous microfungi and plants reduce soil nonylphenol contamination and stimulate resident microfungal communities. Applied Microbiology and Biotechnology 82, 359-370. Isola, D., Marzban, G., Selbmann, L., Onofri, S., Laimer, M. Sterflinger, K., 2011. Sample preparation and 2-DE procedure for protein expression profiling of black microcolonial fungi. Fungal Biology 115, 971-977.

Jorgensen, C., Nielsen, B., Jensen, B.K., Mortensen, E., 1995. Transformation of o-xylene to o-methyl benzoic acid by a denitrifying enrichment culture using toluene as the primary substrate. Biodegradation 6, 141-146.

Junghanns, C., Moeder, M., Krauss, G., Martin, C., Schlosser, D., 2005. Degradation of the xenoestrogen nonylphenol by aquatic fungi and their laccases. Microbiology 151, 45-57.

Kim, Y., Nandakumar, M.P., Marten, M.R., 2007. Proteomics of filamentous fungi. Trends in Biotechnology 25(9), 396-401.

Kroll, K., Pähtz, V., Kniemeyer, O., 2014. Elucidating the fungal stress response by proteomics. Journal of Proteomics 97, 151-163. Krupiński, M., Długoński, J., 2011. Biodegradation of nonylphenols by some microorganisms. Advances in Microbiology 50(4), 313-319. Krupiński, M., Szewczyk, R., Długoński, J., 2013. Detoxification and elimination of xenoestrogen nonylphenol by the filamentous fungus Aspergillus versicolor. International Biodeterioration and Biodegradation 82, 59-66.

Lintelmann, J., Katayama, A., Kurihara, N., Shore, L., Wenzel, A., 2003. Endocrine disruptors in the environment (IUPAC Technical Report). Pure and Applied Chemistry 75, 631-681.

Matsuzaki, F., Shimizu, M., Wariishi, H., 2008. Proteomic and Metabolomic Analyses of the White-Rot Fungus Phanerochaete chrysosporium Exposed to Exogenous Benzoic Acid. Journal of Proteome Research 7, 2342-2350.

Murad, A.M., Laumann, R.A., Lima, T.A., Sarmento, R.B.C., Noronha, E.F., Rocha, T.L., 2006. Valadares-Inglis MC, Franco OL. Screening of entomopathogenic Metarhizium anisopliae isolates and proteomic analysis of secretion synthesized in response to cowpea weevil (Callosobruchus maculatus) exoskeleton. Comparative Biochemistry and Physiology - Part C: Toxicology and Pharmacology 142, 365-370.

Nandakumar, M.P., Shen, J., Raman, B., Marten, M.R., 2003. Solubilization of Trichloroacetic Acid (TCA) Precipitated Microbial Proteins via $\mathrm{NaOH}$ for Two-Dimensional Electrophoresis. Journal of Proteome Research 2, 89-93.

Oliveira, I.M., Bonatto, D., Pega, H.J.A., 2005. Nitroreductases: Enzymes with Environmental Biotechnological and Clinical Importance. In: Mendez-Vilas A. editor: Current Research Technology and Education Topics in Applied Microbiology and Microbial Biotechnology: Badajoz: Formatex, 1008-1019.

Perkins, D.N., Pappin, D.J., Creasy, D.M., Cottrell, J.S. 1999 Probability-based protein identification by searching sequence databases using mass spectrometry data. Electrophoresis 20(18), 3551-3567.

Rabilloud, T., Adessi, C., Giraudel, A., Lunardi, J., 1997. Improvement of the solubilization of proteins in two-dimensional electrophoresis with immobilized pH gradients. Electrophoresis 18(34), 307-316.

Rao, P.K., Li, Q., 2009. Principal Component Analysis of Proteome Dynamics in Iron-starved Mycobacterium Tuberculosis. Journal of proteomics bioinformatics 15:2(1), 19-31.

Ringnér, M., 2008. What is principal component analysis? Nature Biotechnology 26, 303-304.

Różalska, S., Pawłowska, J., Wrzosek, M., Tkaczuk, C., Długoński, J., 2013. Utilization of 4-n-nonylphenol by Metarhizium sp. Isolates. Acta Biochimica Polonica 60(4), 677-682.

Różalska, S., Szewczyk, R., Długoński, J., 2010. Biodegradation of 4-n-nonylphenol by the non-ligninolytic filamentous fungus Gliocephalotrichum simplex: a proposal of a metabolic pathway. Journal of Hazardous Materials 180, 323-331.

Salvachúa, D., Martínez, A.T., Tien, M., López-Lucendo, M.F., García, F., de Los Ríos, V., Martínez, M.J., Prieto, A., 2013. 
Differential proteomic analysis of the secretome of Irpex lacteus and other white-rot fungi during wheat straw pretreatment. Biotechnology for Biofuels 6(1), 115.

Sequencing Grade Modified Trypsin Protocol, 2014. Online at: http://pl.promega.com/resources/protocols/product-information-

sheets/n/sequencing-grade-modified-trypsin-protocol/

Shao, C., Tian, Y., Dong, Z., Gao, J., Gao, Y., Jia, X., Guo, G., Wen, X., Jiang, C., Zhang, X., 2012. The Use of Principal Component Analysis in MALDI-TOF MS: a Powerful Tool for Establishing a Minioptimized Proteomic Profile. American Journal of Biomedical Sciences 4(1), 85-101.

Shaw, J.P., Harayama, S., 1992. Purification and characterization of the NADH: acceptor reductase component of xylene monooxygenase encoded by the TOL plasmid pWWO of Pseudomonas putida mt-2 Eur. Journal of Biochemistry 209, 51-61. Shimizu, M., Wariishi, H., 2005. Development of a sample preparation metod for fungal proteomics. FEMS Microbiology Letters 247, 17-22.

Soares, A., Guieysse, B., Jefferson, B., Cartmell, E., Lester, J.N., 2008. Nonylphenol in the environment: A critical review on occurrence, fate, toxicity and treatment in wastewaters. Environment International 34, 1033-1049.

Spivack, J., Leib, T.K., Lobos, J.H., 1994. Novel Pathway for Bacterial Metabolism of Bisphenol A. Journal of Biological Chemistry 269(10), 7323-7329.

Taubert, J., Krings, U., Berger, R.G., 2000. A comparative study on the disintegration of flamentous fungi. Journal of Microbiological Methods 42, 225-232.

UCSF In-Gel Digestion Protocol, 2014. Online at: https://msf.ucsf.edu/ingel.html

Vazquez-Duhalt, R., Marquez-Rocha, F., Ponce, E., Licea, A.F.,

Viana, M.T., 2005. Nonylphenol, an intergrated vision of a pollutant. Scientific review. Applied Ecology and Environmental Research 4, 1 25

Verhoeckx, K.C., Bijlsma, S., de Groene, E.M., Witkamp, R.F., van der Greef. J., Rodenburg, R.J., 2004. A combination of proteomics, principal component analysis and transcriptomics is a powerful tool for the identification of biomarkers for macrophage maturation in the U937 cell line. Proteomics 4(4), 1014-1028.

Zhang, Y., Gaikwad, N.W., Olson, K., Zahid, M., Cavalieri, E.L., Rogan, E.G., 2007. Cytochrome P450 isoforms catalyze formation of catechol estrogen quinones that react with DNA. Metabolism 56(7), 887-894. 


\section{Intracellular proteome expression during 4-n-nonylphenol biodegradation by the filamentous fungus Metarhizium robertsii}

Rafał Szewczyk $^{\mathrm{a}}$, Adrian Soboń $^{\mathrm{a}}$, Różalska Sylwia $^{\mathrm{a}}$, Katarzyna Dzitko $^{\mathrm{b}}$, Dietmar Waidelich ${ }^{\mathrm{c}}$, Jerzy Długoński $^{\mathrm{a}^{*}}$

$\mathrm{a}^{*}$ Department of Biotechnology and Industrial Microbiology, Institute of Microbiology, Biotechnology and Immunology, Faculty of Biology and Environmental Protection, University of Łódź, Banacha 12/16, 90-237 Łódź, Poland, tel. 4842 63544 60, Fax. 484266558 18, jdlugo@biol.uni.lodz.pl

${ }^{b}$ Department of Immunoparasitology, Institute of Microbiology, Biotechnology and Immunology, Faculty of Biology and Environmental Protection, University of Łódź, Banacha 12/16, 90-237 Łódź, Poland,

${ }^{c} A B$ SCIEX Germany GmbH, Landwehrstrasse 54, 64293 Darmstadt, Germany

\section{SUPPORTING MATERIAL}

\section{Contents}

Table S-1 - page 1

Table S-2 - page 1

Figure S-1 - page 2

\section{Results}

Table S-1. MRM parameters of selected compounds.

\begin{tabular}{ccccccccc}
\hline Name & $\begin{array}{c}\text { Q1 mass } \\
{[\mathrm{Da}]}\end{array}$ & $\begin{array}{c}\text { Q3 mass } \\
{[\mathrm{Da}]}\end{array}$ & $\begin{array}{c}\text { Dwell } \\
{[\mathrm{msec}]}\end{array}$ & $\begin{array}{c}\text { DP } \\
{[\mathrm{V}]}\end{array}$ & $\begin{array}{c}\text { EP } \\
{[\mathrm{V}]}\end{array}$ & $\begin{array}{c}\text { CEP } \\
{[\mathrm{V}]}\end{array}$ & $\begin{array}{c}\text { CE } \\
{[\mathrm{V}]}\end{array}$ & $\begin{array}{c}\text { CXP } \\
{[\mathrm{V}]}\end{array}$ \\
\hline 4-n-NP 1 & 219.2 & 106.0 & 50 & -65 & -9 & -14 & -30 & 0 \\
4-n-NP 2 & 219.2 & 119.1 & 50 & -65 & -9 & -14 & -54 & 0 \\
4-HBA 1 & 136.8 & 93.0 & 50 & -30 & -3.5 & -12 & -22 & 0 \\
4-HBA 2 & 136.8 & 65.0 & 50 & -30 & -3.5 & -12 & -42 & 0 \\
4-HAP 1 & 134.9 & 91.9 & 50 & -40 & -4 & -16 & -30 & 0 \\
4-HAP 2 & 134.9 & 93.0 & 50 & -40 & -4 & -16 & -24 & 0 \\
4-HBAL 1 & 121.1 & 92.0 & 50 & -50 & -5 & -16 & -32 & 0 \\
4-HBAL 2 & 121.1 & 93.0 & 50 & -50 & -5 & -16 & -26 & 0 \\
\hline
\end{tabular}

Table S-2. LC-MS/MS quantitative analysis of selected compounds.

\begin{tabular}{|c|c|c|c|c|c|c|c|c|c|c|c|c|}
\hline \multirow{3}{*}{$\begin{array}{c}\text { Time } \\
{[\mathrm{h}]}\end{array}$} & \multicolumn{3}{|c|}{1} & \multicolumn{3}{|c|}{13} & \multicolumn{3}{|c|}{10} & \multicolumn{3}{|c|}{12} \\
\hline & \multicolumn{3}{|c|}{$\begin{array}{c}4-n-\mathrm{NP} \\
{[\mathrm{mg} / \mathrm{l}]}\end{array}$} & \multicolumn{3}{|c|}{$\begin{array}{c}4-\mathrm{HBA} \\
{[\mathrm{mg} / \mathrm{l}]}\end{array}$} & \multicolumn{3}{|c|}{$\begin{array}{c}\text { 4-HAP } \\
{[\mu \mathrm{g} / \mathrm{l}]}\end{array}$} & \multicolumn{3}{|c|}{$\begin{array}{c}\text { 4-HBAL } \\
{[\mathrm{ng} / \mathrm{l}]}\end{array}$} \\
\hline & $\mathrm{AC}$ & $B C$ & TS & $\mathrm{AC}$ & $\mathrm{BC}$ & TS & $\mathrm{AC}$ & $\mathrm{BC}$ & TS & $\mathrm{AC}$ & $\mathrm{BC}$ & TS \\
\hline 0 & 0 & 0 & 50 & 0 & 0 & 0 & 0 & 0 & 0 & 0 & 0 & 0 \\
\hline 24 & 0 & 0 & 19.32 & 0 & 0.03 & 1.38 & 0 & 0 & 0.45 & 0 & 0.75 & 5.08 \\
\hline 48 & 0 & 0 & 0.99 & 0 & 0.01 & 0.75 & 0 & 0 & 1.61 & 0 & 0.67 & 7.49 \\
\hline 72 & 0 & 0 & 0.49 & 0 & 0 & 0 & 0 & 0 & 0.36 & 0 & 0.59 & 2.26 \\
\hline 96 & 0 & 0 & 0.38 & 0 & 0 & 0 & 0 & 0 & 0.11 & 0 & 0.43 & 0.80 \\
\hline 120 & 0 & 0 & 0.45 & 0 & 0 & 0 & 0 & 0 & 0.14 & 0 & 0.45 & 0.42 \\
\hline
\end{tabular}

AC - abiotic control. BC - biotic control. TS - tested sample 


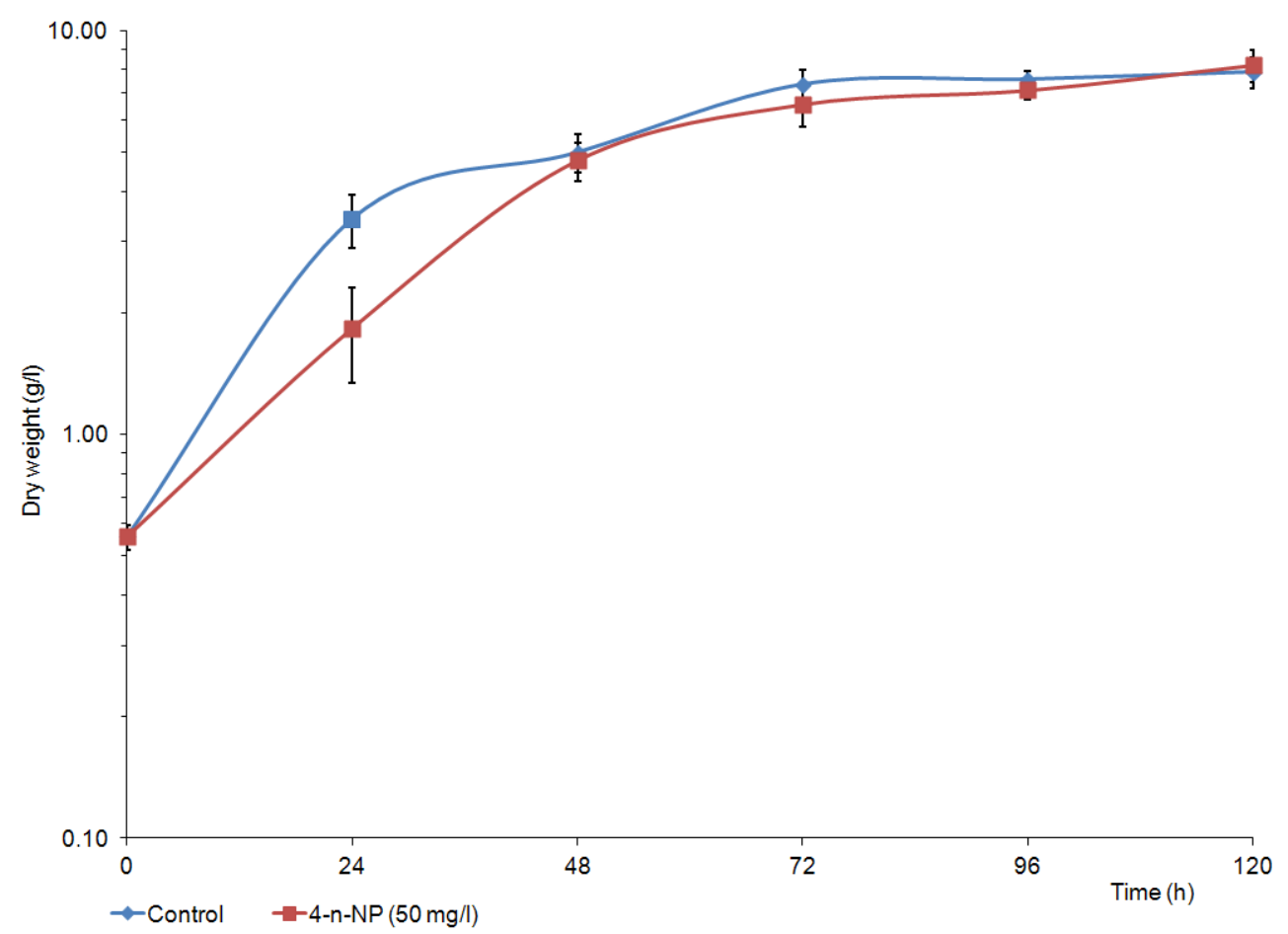

Figure S-1. Dry weight in the cultures of $M$. robertsii with and without 4-n-NP addition. 